\title{
Experimental study on flint hammerstone use in Discoid- Levallois technologies: A comparison with the workshop assemblages of the central Iberian Peninsula
}

\author{
Víctor Lamas Navarro, Sara Díaz Pérez, Guillermo Bustos-Pérez, \\ Felipe Cuartero Monteagudo, Concepción Torres Navas, Javier Baena Preysler
}

Universidad Autónoma de Madrid, Spain.

Email: Navarro: victor.lamas@titulado.uam.es; Pérez: sara.diazp@estudiante.uam.es;

Bustos-Pérez: guillermo.bustos@predoc.uam.es; Monteagudo: felipe.cuartero@uam.es;

Navas: concepcion.torres@uam.es; Preysler: Javier.baena@uam.es

\begin{abstract}
:
The basins of the Manzanares and Jarama rivers have been connected to human activity since the early Palaeolithic. At the boundary between these rivers the abundance of flint has given place to exploitation and mining activities even in historical times. In recent years, projects related to urban expansion in the southeast of Madrid have brought to light various Palaeolithic deposits associated with workshops and tool production. These sites do not have evidence of river pebbles of quartzite, quartz or sandstone in the immediate environment that could have been used as hammerstones, meaning that hammerstones in these raw materials had to be transported and introduced into the sites from large distances. Given this situation, attention was paid to flint elements that show clear signs of being used as hammerstones. The aim of this study is to test the effectiveness of flint as hammerstone, testing whether the use of this raw material is indifferent to other rock types or if you have limitations or advantages in this regard. An experimental protocol was developed, allowing to observe specific knapping behaviours and justifying them in the archaeological and technological context in which they are located.
\end{abstract}

Keywords: flint hammerstone; open air sites; recycling; knapping; Middle Palaeolithic sites

\section{Resumen:}

Las cuencas del Manzanares y el Jarama, se han relacionado con actividad humana desde los inicios del Paleolítico. Nuestra área de estudio se encuentra situada en la Plataforma divisoria entre dichos ríos. El sílex, muy abundante en dicha área fue empleado por los distintos grupos humanos recurrentemente, incluso en tiempos históricos.

En los últimos años, los distintos proyectos de ampliación urbana del sureste de la ciudad de Madrid han sacado a la luz diversos yacimientos asociados a talleres de producción de herramientas. El sílex juega un papel fundamental en esta área. En estos yacimientos no tenemos evidencias de cantos de río en cuarcita, cuarzo o arenisca en el entorno inmediato que sean susceptibles de ser empleados como percutores. No obstante, sí aparecen percutores en estas materias primas que son

Published by the School of History, Classics and Archaeology, University of Edinburgh ISSN: 2055-0472. URL: http://journals.ed.ac.uk/lithicstudies/

This work is licensed under a Creative Commons Attribution 2.5 UK: Scotland License. 
claramente aportados a los yacimientos desde mayores distancias. Dada esta situación, llaman especialmente la atención los elementos en sílex que presentan claras huellas de haber sido empleados en la percusión.

La existencia de éste tipo de percutores nos puede mostrar dos concepciones distintas: por un lado, un uso inmediato de la materia prima más cercana y por otro el reciclaje de elementos previamente desechados o agotados. También es probable un doble uso de una misma herramienta, como es el caso de los bifaces y percutores.

El planteamiento principal, en este caso de estudio, era comprobar la eficacia del sílex como percutor. Por medio de la experimentación, podemos comprobar si el empleo de esta materia prima resulta indiferente con respecto a otros tipos de rocas o si presenta dificultades o ventajas en este sentido. Para alcanzar dicho objetivo se ha planteado un programa experimental específico. Con esta experimentación tratamos de observar comportamientos concretos de los talladores y justificarlos enmarcándolos dentro del contexto en el que se encuentran.

Palabras clave: percutores de sílex; yacimientos al aire libre; reciclaje; talla; yacimientos de Paleolítico Medio

\section{Introduction}

The Evidence relating the re-use of flint cores and handaxes as hammerstones has become increasingly available (Moncel 1999; Claud et al. 2010 Thiébaut et al. 2010; Baena et al. 2015a). In recent years, projects related to the urban expansion in the southeast of Madrid have brought to light various Palaeolithic deposits associated with workshops and tool production where the use of flint hammerstones seems to be a common feature. The analysis of archaeological and experimental hammerstones can provide additional and complementary information for the understanding of the technical limitations of this raw material and thus an approximation to Neanderthal catchment behaviour. The effectiveness or ineffectiveness of these hammerstones may indicate two specific aspects: firstly, an absence of planning and an adaptive solution for eventual knapping behaviours, and secondly, the existence of learning processes in which the use of these hammerstones is an opportunistic solution for low technological agents. The aim of this study is to test the initial hypothesis that flint hammerstones are not as effective as quartzite, sandstone, granite or other raw materials.

The study-area is located in the centre of the Iberian Peninsula, in the Community of Madrid; within the Miocene age Madrid Basin, which is dissected by the Central System, and a dense river network. The northern and southern margins of the Madrid Basin consist of granitic igneous rocks that contrast with the basin units formed by lacustrine and alluvial materials (arkoses with carbonates, clays and gypsum) (López-Camacho et al. 1986). During the period of the Neogene there were three large sedimentary stages that are associated with three large stratigraphic units in relation to flint formations: Lower Unit (Middle RablienseAragoniense), Middle Unit (Middle Aragoniense-Lower Vallesiense) and Upper Unit (Upper Vallesiense-Turoliense) (Baena et al. 2015b; Calvo et al. 1996). The Lower Unit is formed by massive gypsums and clayey sequences (silt and clay formations) intercalated with conglomerates, sandstones and limestones. The Intermediate Unit presents green clays with flint nodules and opals (Barez \& Pérez-González 2007; Bustillo \& Pérez-Jiménez 2005). The final Upper Unit consists principally of fluvial terrigenous deposits and shallow lacustrine carbonates (Giner et al. 1996). The diagenetic processes of this Neogene stratigraphic series have resulted in a great abundance of flint and consequently this has become a source area of this type of raw material (Figure 1). Sites studied here are located in two urbanized areas that are part of different municipalities of Madrid. The first archaeological site is called Calabazas I, and it is located at Vicálvaro, while the other archaeological sites known as CPD30 and Parcela 32 are located in Coslada. Each of these sites presents particular models of deposits 
associated to the course of the rivers and the local geological abundance of flint (Rus 1987; Baena Preysler et al. 2000) (Figure 1).

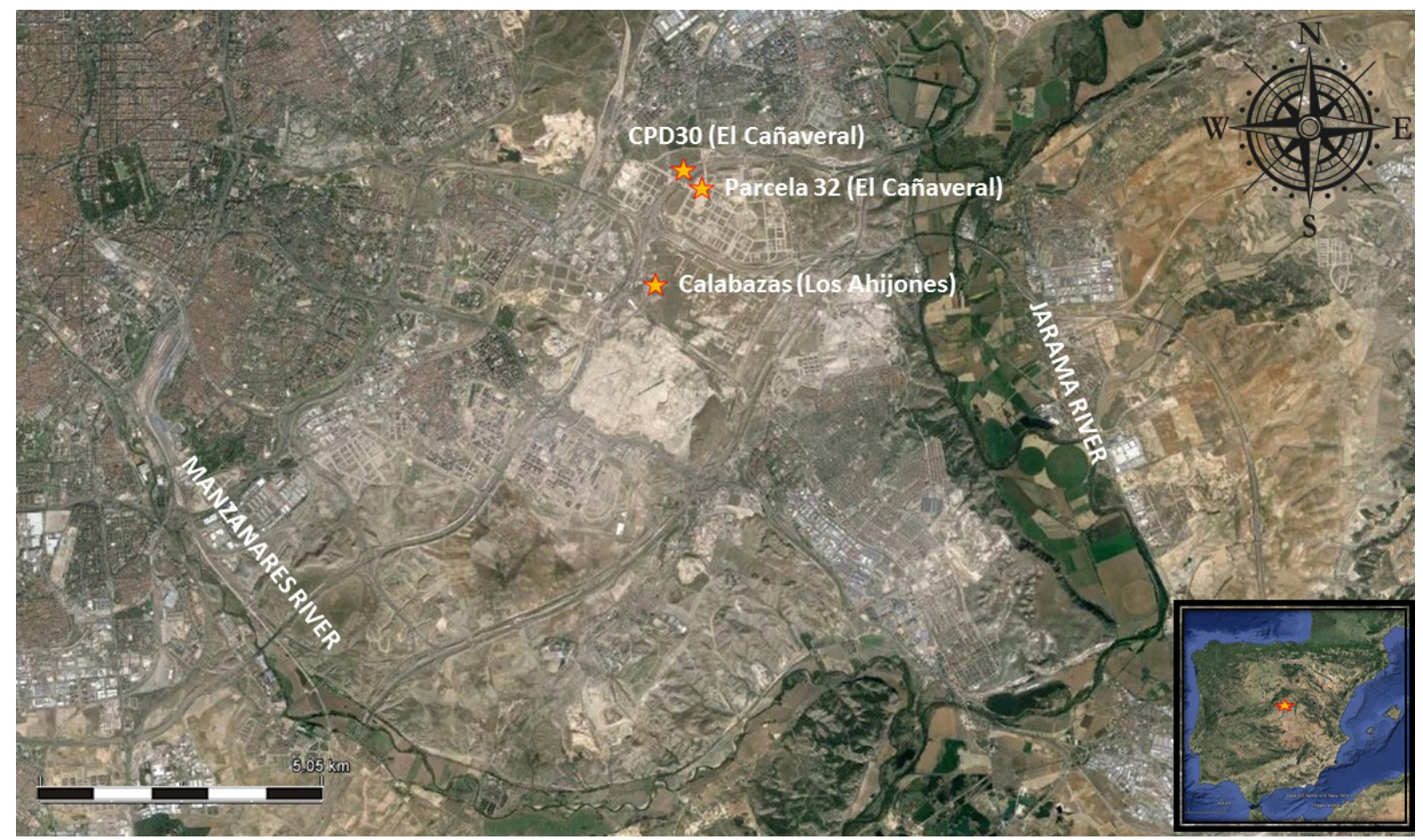

Figure 1. Middle Palaeolithic sites in the southeast Madrid. (Aerial Photography from Google Earth Pro).

\subsection{Archaeological and technological context: Calabazas I, Parcela 32 and CPD30 sites}

\section{Calabazas I}

The archaeological fieldwork carried out in Calabazas I started in 2012 when concentrations of lithic industries in primary position were found (Bárez et al. 2011). Although some displacement of the pieces by minor run-off can be observed, the conservation is optimal and their displacement is minimal. The formation of this type of run-off is associated with a stream in the area; we observe that there are areas where this process is repeated. The fact that floods occur in specific episodes, allows us to place the pieces in a particular geologic and stratigraphic context in which the sediment layers have protected the site. The archaeological study of this site has offered a wide range of reduction sequences. In this archaeological site, all stages of the various chaînes opératoires are represented starting with small flake blanks. Only large tested elements or initial core preparation (mise en forme) products are absent. The study of these materials confirmed the use of preferential Levallois and recurrent centripetal Levallois methods. Retouched elements (retouched flakes or scrapers) are present in contrast with other sites such as Parcela 32 were they are poorly represented. Core analysis from this site shows a high rate of exploitation, with an average maximum size $3 \mathrm{~cm}$ smaller than cores from the other archaeological sites studied, indicating that exploitation was carried out until exhaustion at Calabazas I. The average size of cores in Calabazas is $5.83 \times 4.75 \times 2.64 \mathrm{~cm}$.

\section{Parcela 32}

At Parcela 32, there have been different sedimentary processes related to karstic processes of the lower unit that occurred throughout the plateau dividing of the Manzanares and Jarama Rivers (Baena et al. 2008; Bravo et al. 2013). This area presents a siliceous rock 
outcrop from where the raw material was extracted to make stone tools. At this archaeological site, the first stages of the operational chain are documented, such as mise en forme flakes and materials predominantly consisting of cortical flakes, blades, cores, and fragments, while retouched tools are very poorly represented. The study of these materials confirmed the existence of operational chains of recurrent centripetal Levallois and unipolar point production. Analysis of cores from Parcela 32 shows that reduction was not carried out until exhaustion, as was the case at Calabazas I. The average size of cores in P32 is $7.21 \times 7.79 \times 4.48$ $\mathrm{cm}$.

\section{CPD30}

This archaeological site is part of a larger set of sites called the Cañaveral (Coslada, Madrid). In this area, several construction projects have uncovered a significant concentration of lithic artefacts (Baena et al. 2011). During the Pleistocene, colluvium and aeolian processes protected the site from external erosive agents, allowing the preservation of this site and others found at El Cañaveral. During the excavation, circular concentrations of lithic material apparently corresponding to knapping clusters were documented (Torres \& Baena 2014). Based on techno-typological parameters, there is a predominance of recurrent centripetal Levallois and discoid schemes, similar to other schemes from El Cañaveral.

\section{Methods}

\subsection{Experimental protocol}

How effective were the flint hammerstones used at these sites? Why were flint hammerstones used within this specific catchment context? Are there differences in the byproducts derived from the use of flint hammerstones? To answer these questions an experimental protocol was developed. Eleven experiments were carried out: eight experiments involving direct percussion with flint hammerstones, and three experiments with other raw materials (quartzite, sandstone and granite).

To perform the experiments different guidelines were followed:

- Knapping experiments were carried out by two highly skilled knappers. Likewise, two types of flints were differentiated according to their composition: flint 1 - coarse grained and flint 2 - cryptocrystalline, both with a homogeneous internal structure.

- Firstly, the knappers carried out two experiments following a discoid scheme and Levallois scheme on both types of flint.

- To carry out the experiment we took various experimental flint cores made with different types of flint from the Madrid region. These cores were reused as hammerstones. Morphology, dimensions (length, width and thickness), volume and weight of these cores were measured, allowing for a wide selection of cores that could be reused as hammerstones.

- In three other experiments, hammerstones made of other raw materials were used, allowing to compare effectiveness with flint hammerstones. Three experiments, based on discoid reductions (a very productive system for obtaining flakes), were carried out.

- Based on these parameters, a sample of potential experimental hammerstones was provided to the knappers so they could choose between them. Measures of these hammerstones were taken so that they would be comparable to those observed among the archaeological record.

- During the experiment, the failed impacts and the products obtained were counted. A failed strike is considered one in which obtaining of a flake blank is not accomplished. A successful strike is considered one in which the core is reduced though the detachment of flake blanks. Among the products obtained we counted those larger than $2 \mathrm{~cm}$ and with clear 
morphological features (platform, ventral surface and dorsal surface). Successful and failed strikes were counted manually and recorded using a video camera for subsequent analysis and re-counting.

- Finally, we analysed the characteristics of the stigmata visible on the hammerstones in order to better define them and their evolution among the surface of the flint hammerstone. These data were compared to the archaeological hammerstones, and this has helped us to identify the direction and angle of use.

\subsection{Analysis of hammerstones and obtained flakes}

\subsubsection{Hammerstone analysis}

Experimental and archaeological hammerstones were analysed following the same protocol. Measures of length, width, and thickness were obtained using a digital calliper, and weight was measured using a digital scale. Volume was obtained by placing the hammerstones in a graduated cylinder, measuring the displacement of water, and then solving the equation for the volume of a cylinder $(\mathrm{V}=\pi \mathrm{r} 2 \mathrm{~h})$. Each hammerstone was photographed with a digital camera (PANASONIC LUMIX DMC-LZ40) before (in the case of experimental flint hammerstones) and after use, using a cubic decomposition model that allowed to photograph each face of the hammerstone. Detailed microphotographs were obtained using a Digital Microscope (USB 500X).

As part of the hammerstone analysis the active zone of percussion (henceforth AZP) was defined (following Cuartero, 2010; 2014) for each hammerstone. AZP is defined by the concentration of percussion stigmas that increase with the use of the hammerstone. AZP was localized and defined for each hammerstone, measuring maximum length and width.

\subsubsection{Analysis of products obtained through experimentation}

Flakes obtained through experimental use of flint and other raw material hammerstones were analysed. Flake blanks smaller than $2 \mathrm{~cm}$ or without well-defined technical features (percussion platform, bulb of percussion, or clear ventral and dorsal surfaces) were left out of the analysis. Length, width, and thickness of each flake blank were measured along with maximum length and width of the percussion platform. This allowed measures of elongation, which are considered as elements of higher knapping and core efficiency.

\section{Results}

\subsection{Metric comparison of experimental flake blanks}

The count of failure versus success in hammerstone percussions suggests that flint hammerstones are less effective when compared with other raw material hammerstones (quartzite, sandstone and granite). Significantly, in the experiments carried out with flint hammerstones, the error rate is higher (57.36\% average) than the hammerstones made of other raw materials (quartzite, sandstone and granite) where there are fewer number of failures (40.42\% on average) (Table 1 ).

In addition, there is a high variability between the different lithic reduction systems (in this case Levallois and discoid schemes). Flake morphology is another aspect to be considered. In our study, we observed that the flakes obtained by flint hammerstones tend to be short (Table 2). Regarding this, we note that average dimensions of flakes obtained by percussion with flint hammerstones are $4.29 \mathrm{~cm}$ long and $3.98 \mathrm{~cm}$ wide. That is, the flakes are practically as long as they are wide; a significant finding considering that this occurs in most of the products produced by flint hammerstones and at all stages of reduction (Table 2). Similarly, the metric analysis of the platforms for all reduction stages produces an average 
width of $2.48 \mathrm{~cm}$ and average thickness of $0.93 \mathrm{~cm}$ (Table 3). This indicates that in the case of the flint hammerstones raw material limits the propagation of the fracture wave and produces fractures and smaller flakes.

Table 1. Relationship between flake success and failure using flint hammerstone and other raw materials.

\section{Strike Fail Flake Failure rate Hammerstone material}

\begin{tabular}{lccccc}
$\operatorname{Exp} 1$ & 279 & 128 & 151 & $46 \%$ & Flint \\
$\operatorname{Exp} 2$ & 123 & 84 & 39 & $68 \%$ & Flint \\
$\operatorname{Exp} 3$ & 138 & 77 & 61 & $56 \%$ & Flint \\
$\operatorname{Exp} 4$ & 70 & 41 & 29 & $59 \%$ & Flint \\
$\operatorname{Exp} 5$ & 126 & 95 & 31 & $\mathbf{7 5 \%}$ & Flint \\
$\operatorname{Exp} 6$ & 61 & 28 & 33 & $46 \%$ & Flint \\
$\operatorname{Exp} 7$ & 110 & 56 & 54 & $51 \%$ & Flint \\
$\operatorname{Exp~8}$ & 240 & 149 & 91 & $62 \%$ & Flint \\
\hline Total & $\mathbf{1 4 3 . 4}$ & $\mathbf{8 2 . 3}$ & $\mathbf{6 1 . 1}$ & $\mathbf{5 8 \%}$ & \\
\hline $\operatorname{Exp} 9$ & 47 & 19 & 28 & 40.42 & Sandstone \\
$\operatorname{Exp~10}$ & 46 & 21 & 25 & $45.65 \%$ & Quartzite \\
$\operatorname{Exp~11}$ & $\mathbf{4 8}$ & 17 & 31 & $35.41 \%$ & Granite \\
\hline Total & $\mathbf{4 7}$ & $\mathbf{1 9}$ & $\mathbf{2 8}$ & $\mathbf{4 0 . 4 0 \%}$ & \\
\hline
\end{tabular}

Table 2. Average sizes of flakes made with flint-hammerstones.

\begin{tabular}{lccc} 
Products & Length average & Width average & Raw material \\
exp1 & 4.68 & 4.26 & flint \\
exp2 & 3.97 & 3.97 & flint \\
exp3 & 5.02 & 4.41 & flint \\
exp4 & 3.45 & 4.04 & flint \\
exp5 & 3.48 & 2.98 & flint \\
exp6 & 4.35 & 3.60 & flint \\
exp7 & 4.64 & 3.95 & flint \\
exp8 & 4.70 & 4.67 & flint \\
\hline Total & 4.29 & 3.98 & \\
\hline exp 9 & 4.06 & 3.79 & sandstone \\
exp 10 & 5.20 & 4.18 & granite \\
exp 11 & 5.09 & 5.46 & quartzite \\
\hline Total & $\mathbf{4 . 7 8}$ & 4.48 & \\
\hline
\end{tabular}

\subsection{Hammerstone preparation}

The experimental process has also provided aspects related to hammerstone preparation and flint knapping:

a) During the experiments, a particular behaviour was documented showing a prior preparation of the core used as hammerstone. In these cases, we can observe that the edges of the core were "softened" with two clear objectives: to regularize the surface of the hammerstone increasing its efficiency, and to facilitate gripping the core during percussion. The edges or ridges were softened as a result of direct percussion on these edges of the cores previously selected based on their morphology and volume. This type of preparation is observed in some archaeological hammerstones whose edges have been softened and where stigmata resemble retouch. 
b) Percussion is usually done using convex surfaces, preferably in areas of convergence of edges (ridges or crêtes) (Figure 2). Furthermore, it has been observed that more pointed morphologies are employed in the discoid method whereas flat and slightly convex surfaces are preferably employed in the Levallois technique. This may be related to abrasion and faceting required as part of the Levallois technique (Figure 3).

Table 3. Average sizes of striking platforms for flakes produced with flint hammerstones.

\begin{tabular}{lccc} 
Striking platform & Width average & Thickness average & Raw material \\
exp1 & 2.47 & 0.87 & flint \\
exp2 & 2.89 & 0.88 & flint \\
exp3 & 2.57 & 0.95 & flint \\
exp4 & 2.41 & 0.88 & flint \\
exp5 & 2.03 & 0.91 & flint \\
exp6 & 2.38 & 1.15 & flint \\
exp7 & 2.52 & 0.81 & flint \\
exp8 & 2.56 & 0.99 & flint \\
\hline Total & $\mathbf{2 . 4 8}$ & $\mathbf{0 . 9 3}$ & \\
\hline exp 9 & 2.27 & 0.97 & sandstone \\
exp10 & 2.42 & 1.28 & granite \\
exp11 & 3.30 & 1.70 & quartzite \\
\hline Total & $\mathbf{2 . 6 6}$ & $\mathbf{1 . 3 2}$ & \\
\hline
\end{tabular}

c) Among the experimentation, it has also been observed that cortical areas were found to be more favourable than other areas of the hammerstone for abrading and faceting. These areas were used for abrasion and platform preparation that are characteristic of Levallois technique. (Figure 3A)

d) Although the main focus of this study is not a deep analysis and classification of the stigmas, macroscopic analysis of the AZP allowed us to observe the direction in which flint hammerstones were used (Figure 4). The stigmas identified (striations, crescents, parasite flakes, or crushing) sometimes overlap each other, and sometimes they are found isolated as a result of percussion mistakes, accidental strikes, or testing of an area. In any case, they help to identify percussion directions in an AZP.

e) The stigmata of the flint hammerstones develop throughout the knapping process (Figure 5). This development is essential in analysing the effectiveness of the flint hammerstone since hammerstone improvement during the knapping process is associated to the development of the stigmata. However, these stigmas may become the direct cause of the break and the end of the use life of the hammerstone due to its increasing fragility (Figure 6). This can be observed in two of the experimental flint hammerstones. 

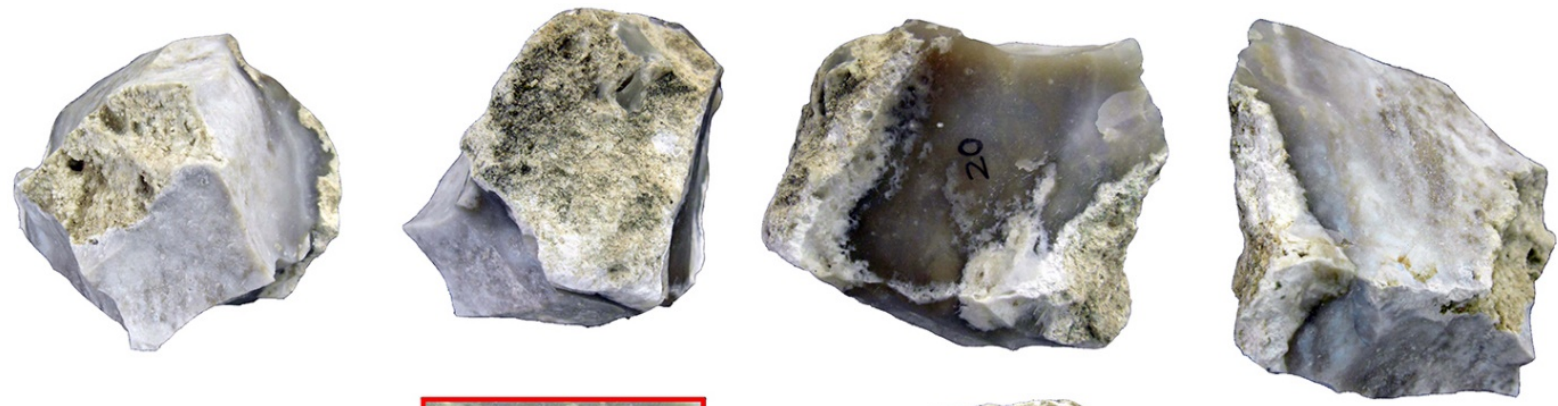

A
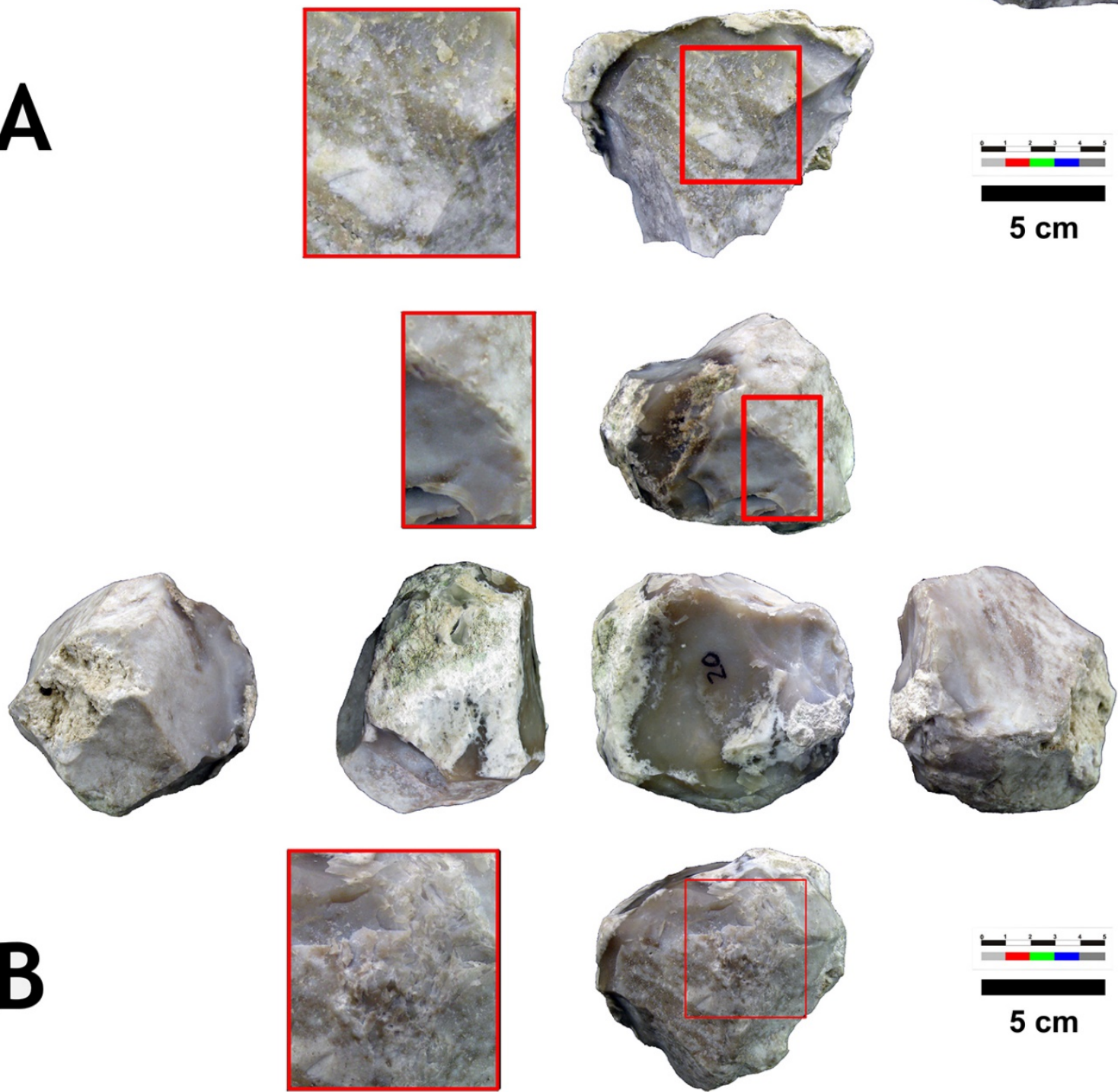

Figure 2. Experimental flint hammerstone before (A) and after use (B). Softening of the edges as preparation for use can be observed (upper rectangle and close-up), as well as the AZP (lower rectangle and close-up). 


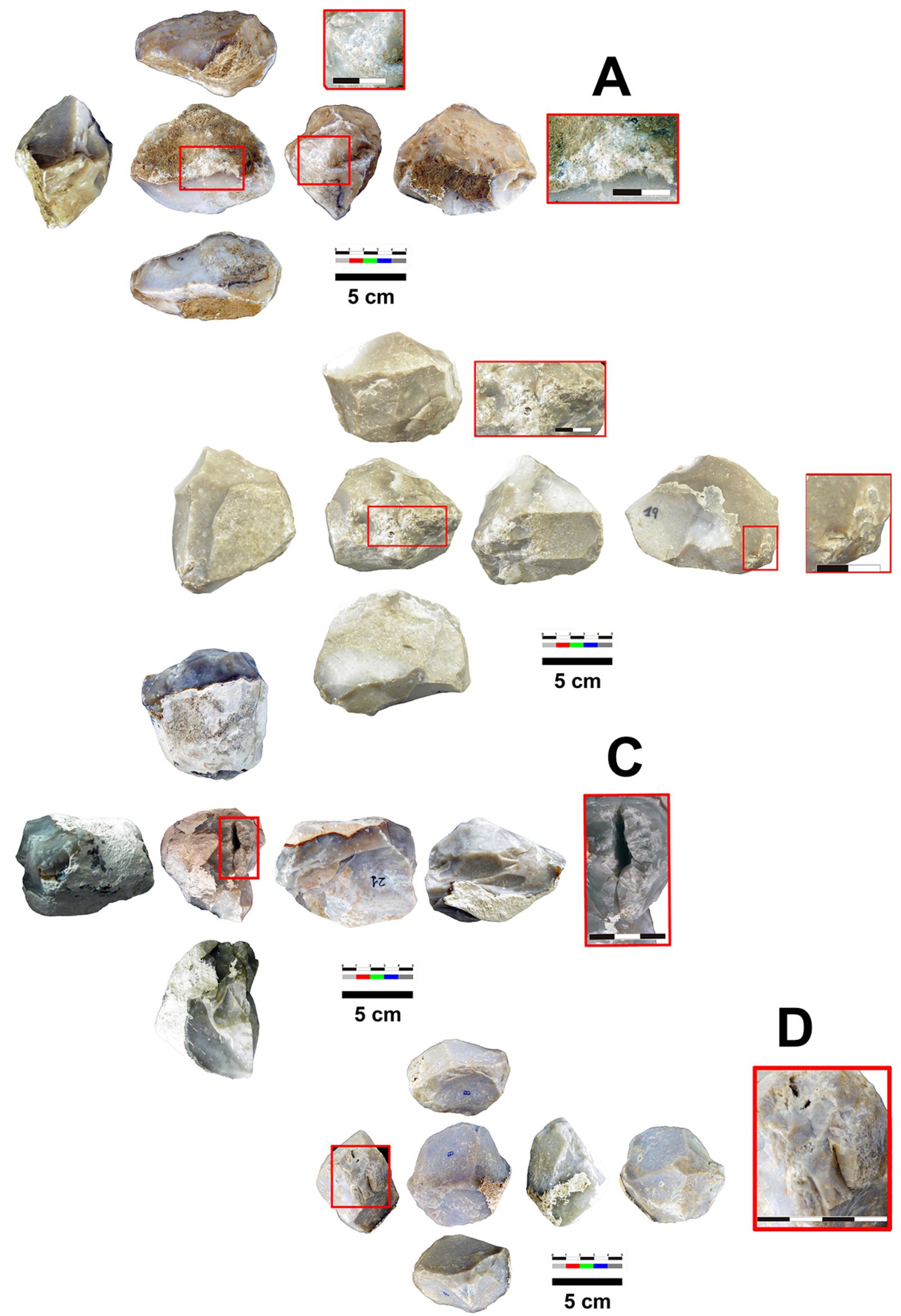

Figure 3. Selection of flint hammerstones used in different experiments. 

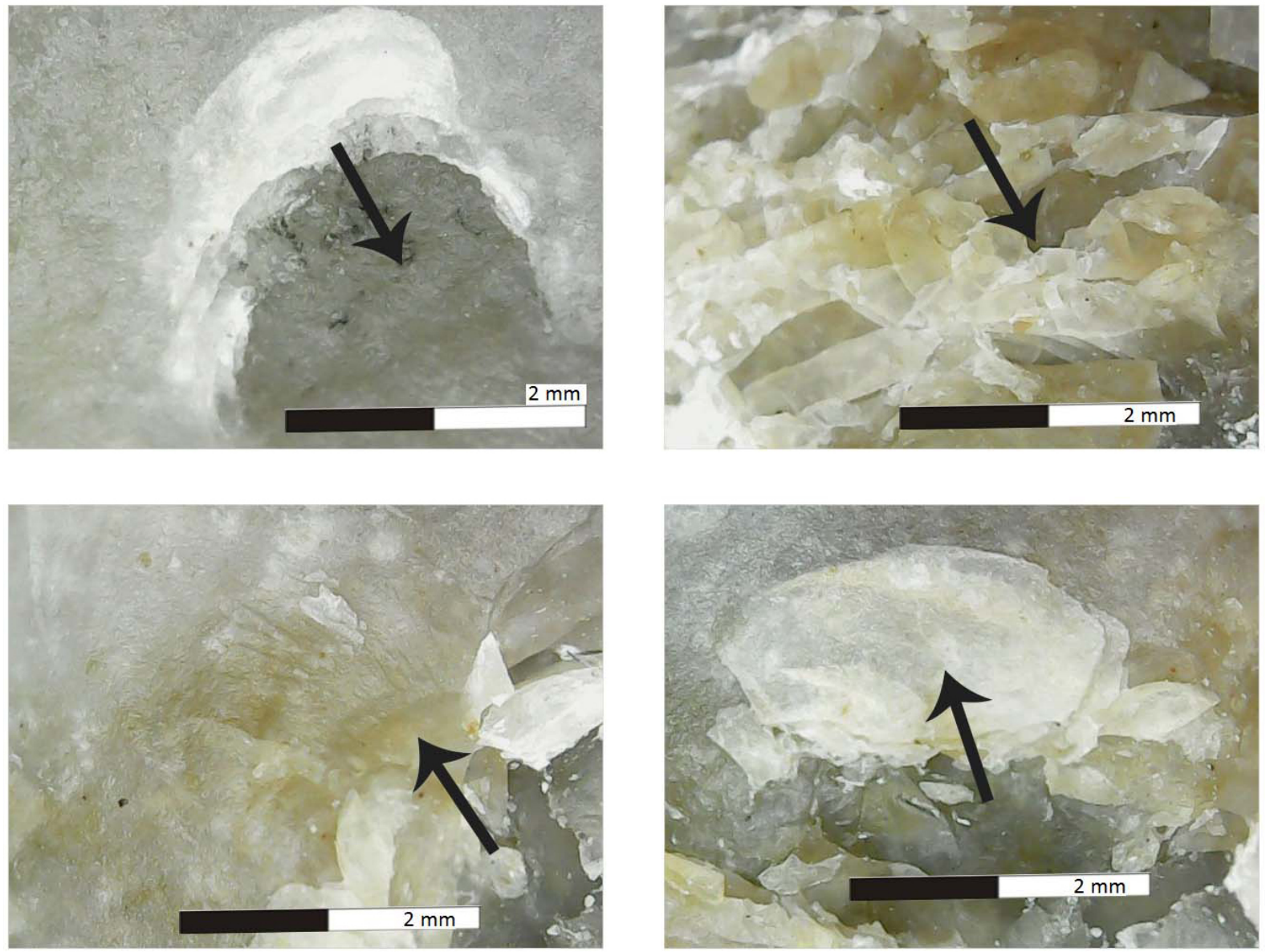

Figure 4. Percussion marks of the flint that can aid in the identification of the use direction of a hammerstone.

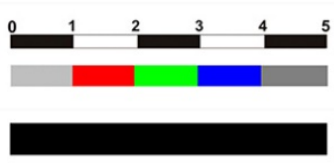

$5 \mathrm{~cm}$
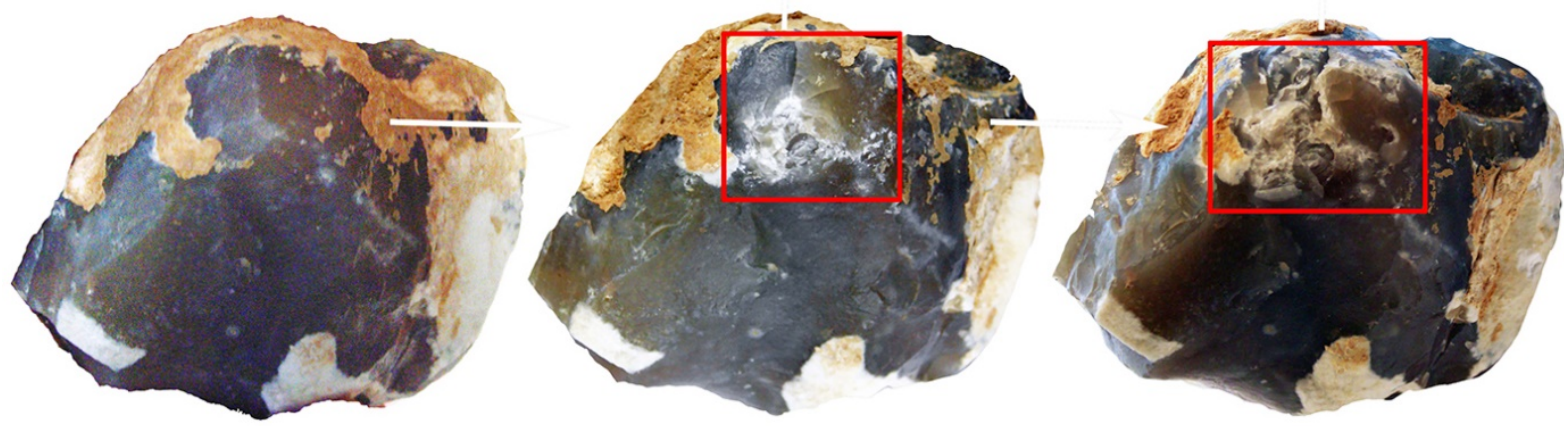

Figure 5. Experimental development of the stigmata on an AZP of a flint hammerstone. 

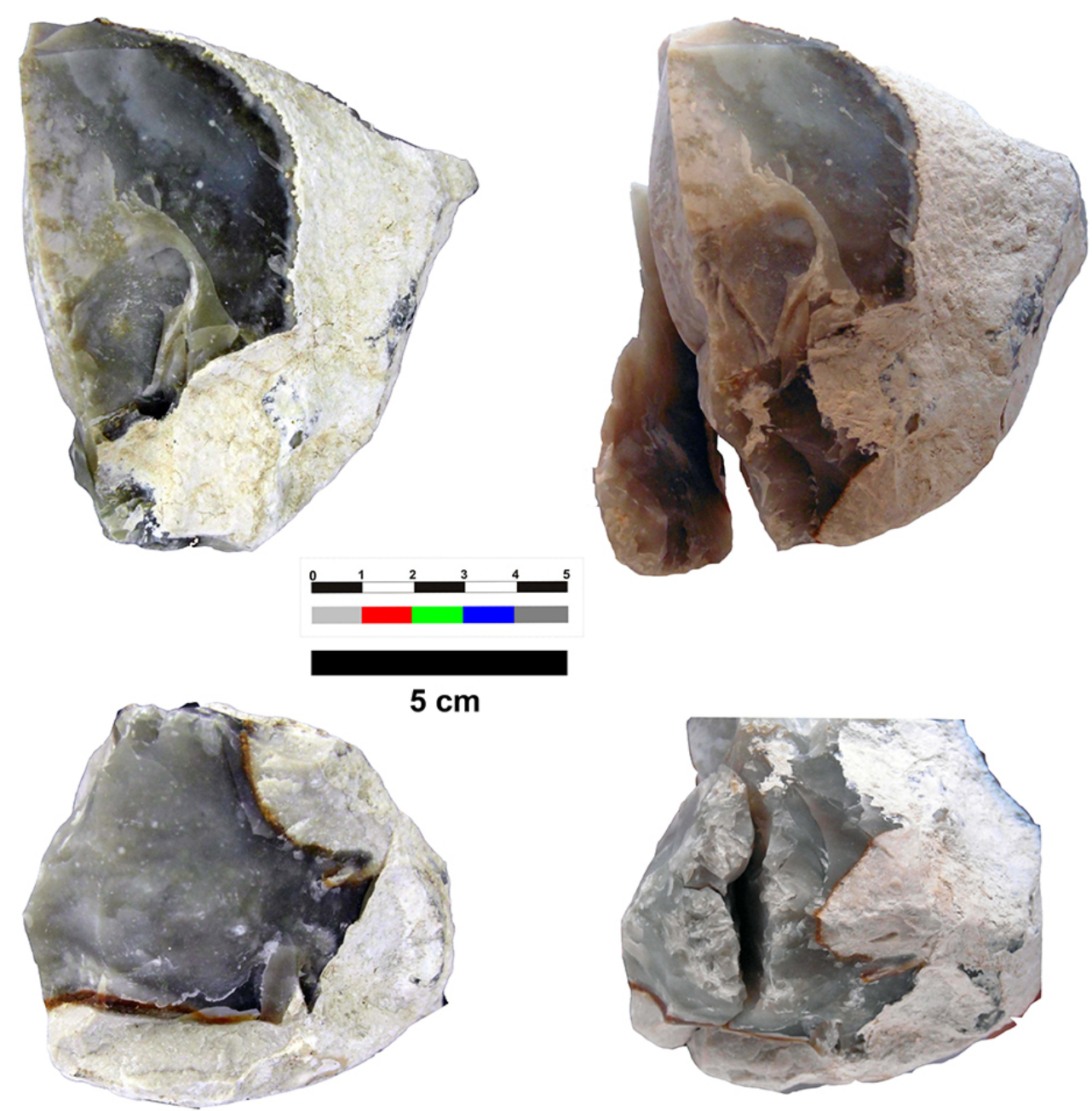

Figure 6. Example of experimentally broken hammerstones. The break has produced a flake. This flake presents a striking platform composed of numerous previous strikes or impacts.

\section{Comparison of archaeological and experimental hammerstones}

\subsection{Archaeological hammerstones}

Archaeological flint hammerstones presented here come from three archaeological sites southeast of Madrid, and as we have seen, respond to different models of flint catchment.

\section{Calabazas I flint hammerstones}

There are two similar flint hammerstones documented in Calabazas I. The measures are related to the size and the reduction system documented in this archaeological site (Figure 7). There is a clearly reused core (Figure 7B) and the second one does not present any apparent preparation. In the second case, we can establish that they are flint hammerstones because of the stigmata, easily recognizable at a macroscopic level and that are characteristic of this type of work (Figure 7A). In addition, splintering of the percussive area occurs in both cases. Stigmas can be observed in areas where the hammerstones generate dihedral angles, which can provide greater precision in the striking. In both cases, we also find small extractions next to the AZP side, produced by faceting movements. These small extractions are documented experimentally in different tasks (Claud et al. 2010), as well as experimentation itself. In the case of the core-hammerstone, we can observe stigmas indicating breakage of the AZP (Figure 7B). 

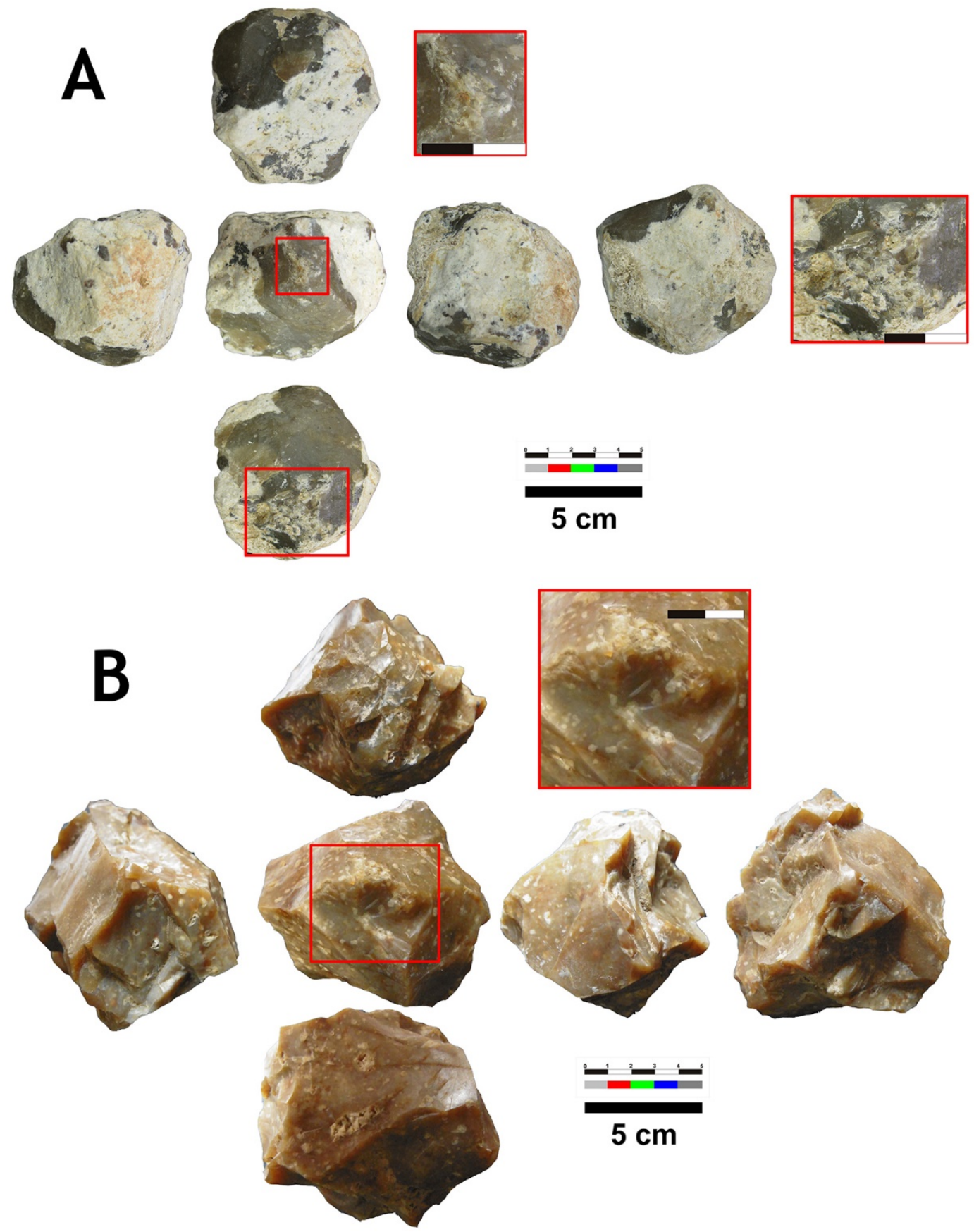

Figure 7. Archaeological flint hammerstone from Calabazas I site (Madrid, Spain). A) Hammerstone (Calabazas 2013) unmodified nodule of local raw material, no recycling. B) Core recycled into a hammerstone (Calabazas2012). It presents a clear fracture within the AZP (rectangle).

\section{Parcela 32 flint hammerstones}

From this archaeological site, several $(\mathrm{N}=7)$ flint elements showing signs of percussion were analysed. The flint hammerstone number 3862 (Figure 8B) is the largest by size, weight, and volume and the smallest of this group is the hammerstone bnc1a (Figure 8A). Metric analysis of the hammerstones found in Parcela 32 shows a great variability in size (Figure 8). The lithic assemblage documented in Parcela 32 is larger in dimensions than at the site of Calabazas I, so the flint hammerstones of this site appear to be larger than at Calabazas I. In Parcela 32, there are three flint hammerstones with very marked use signs on the surface. In addition, the existence of a hammerstone made out of a preferential Levallois core clearly 
indicates the existence of the re-use or recycling of cores as hammerstones (Figure 8D). Finally, we have also observed a mise en forme flake used as a hammerstone.

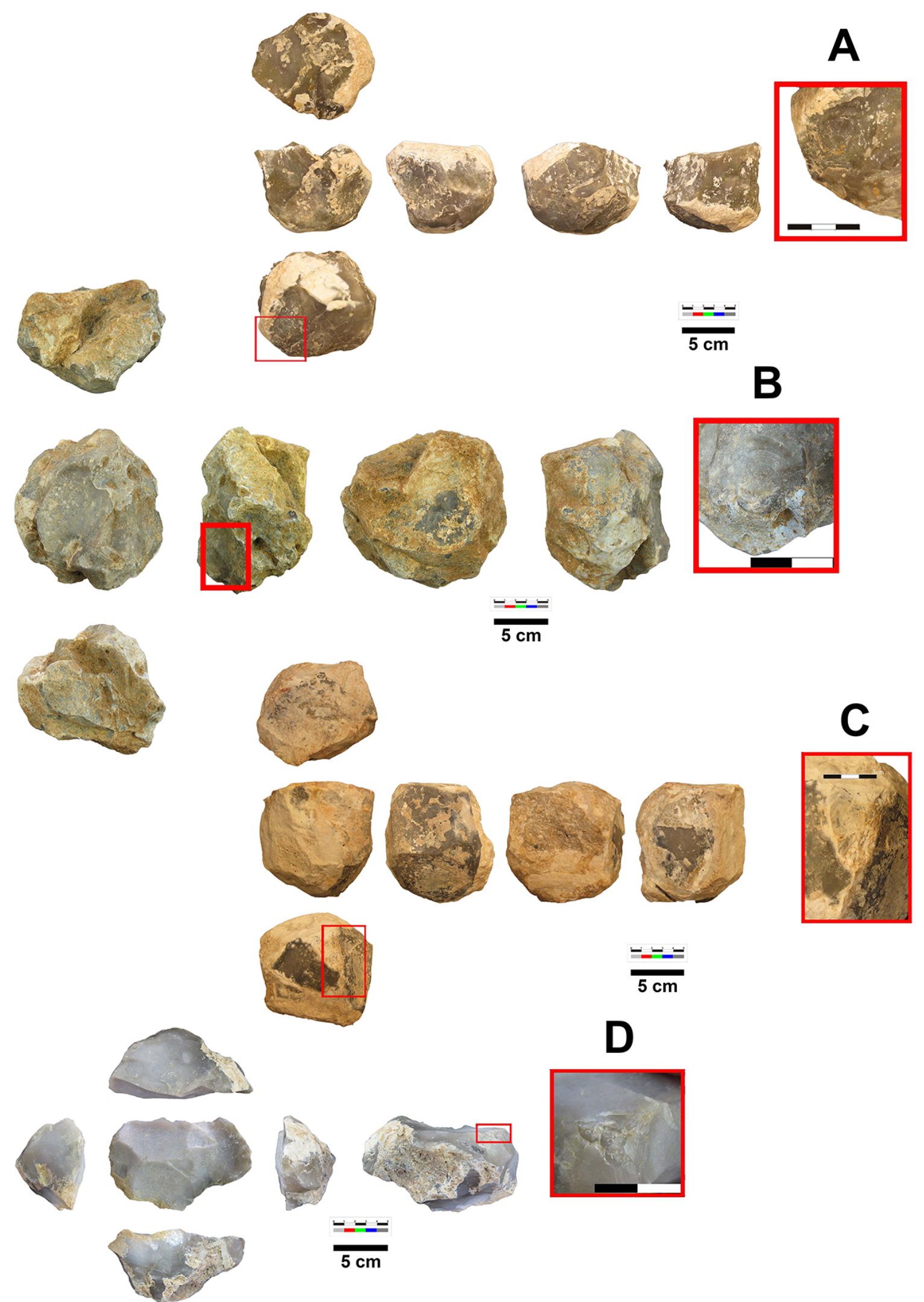

Figure 8. A, B \& C) Recorded archaeological hammerstones in Parcela 32 and their AZPs (rectangle). D) Preferential core recycled as a hammerstone. 


\section{CPD30 flint hammerstones}

There are 6 flint hammerstones at this archaeological site that present similar characteristics to those of Parcela 32 (Figure 9) although metrically they have a greater variability. One of them presents a more intensive use (Figure 9A) than the hammerstones (Figure 9B and 9C) which displays isolated stigmas (crescents) that might belong to isolated strikes that represent non-productive detachments or an expeditious use of that side as a hammerstone.
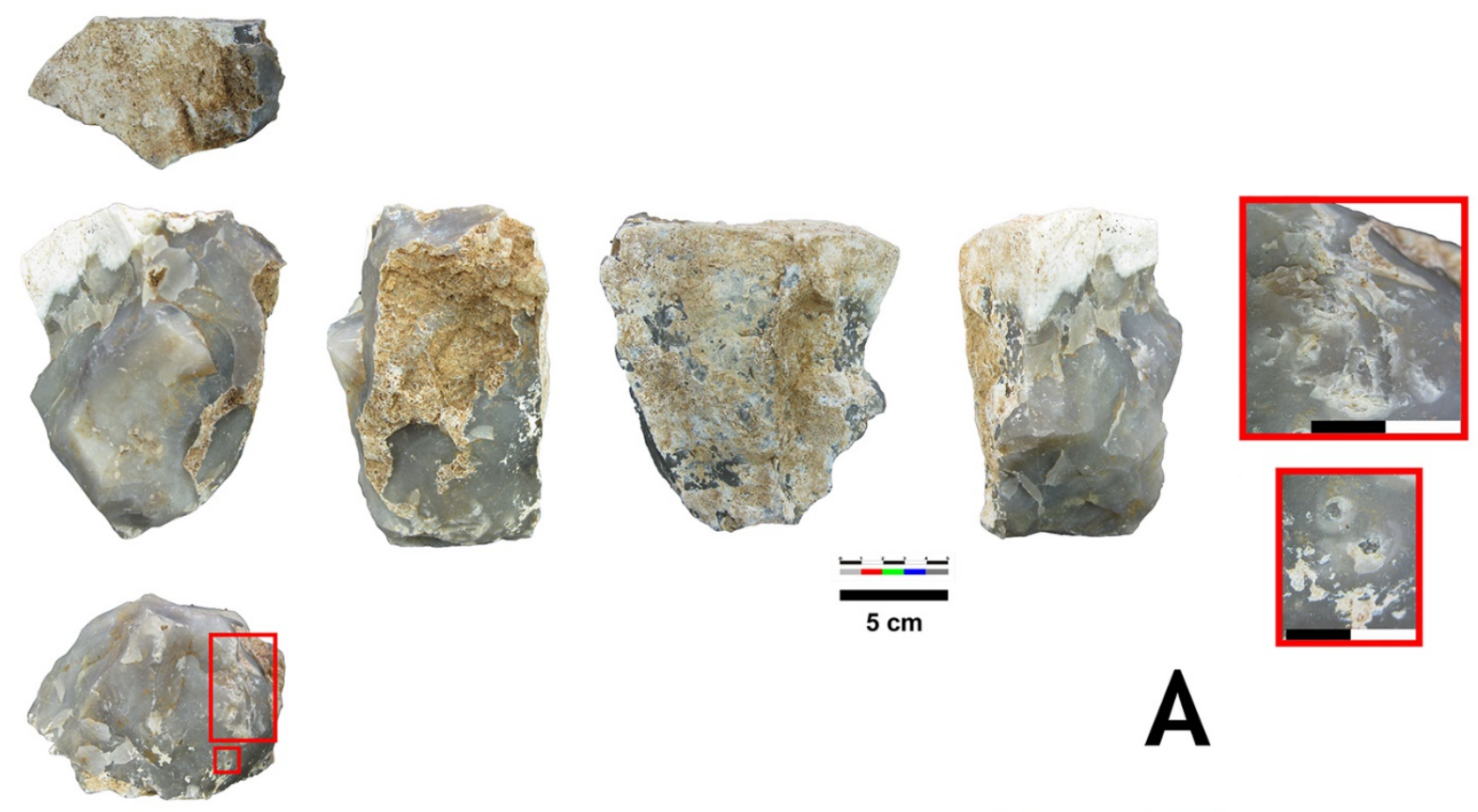

\section{A}
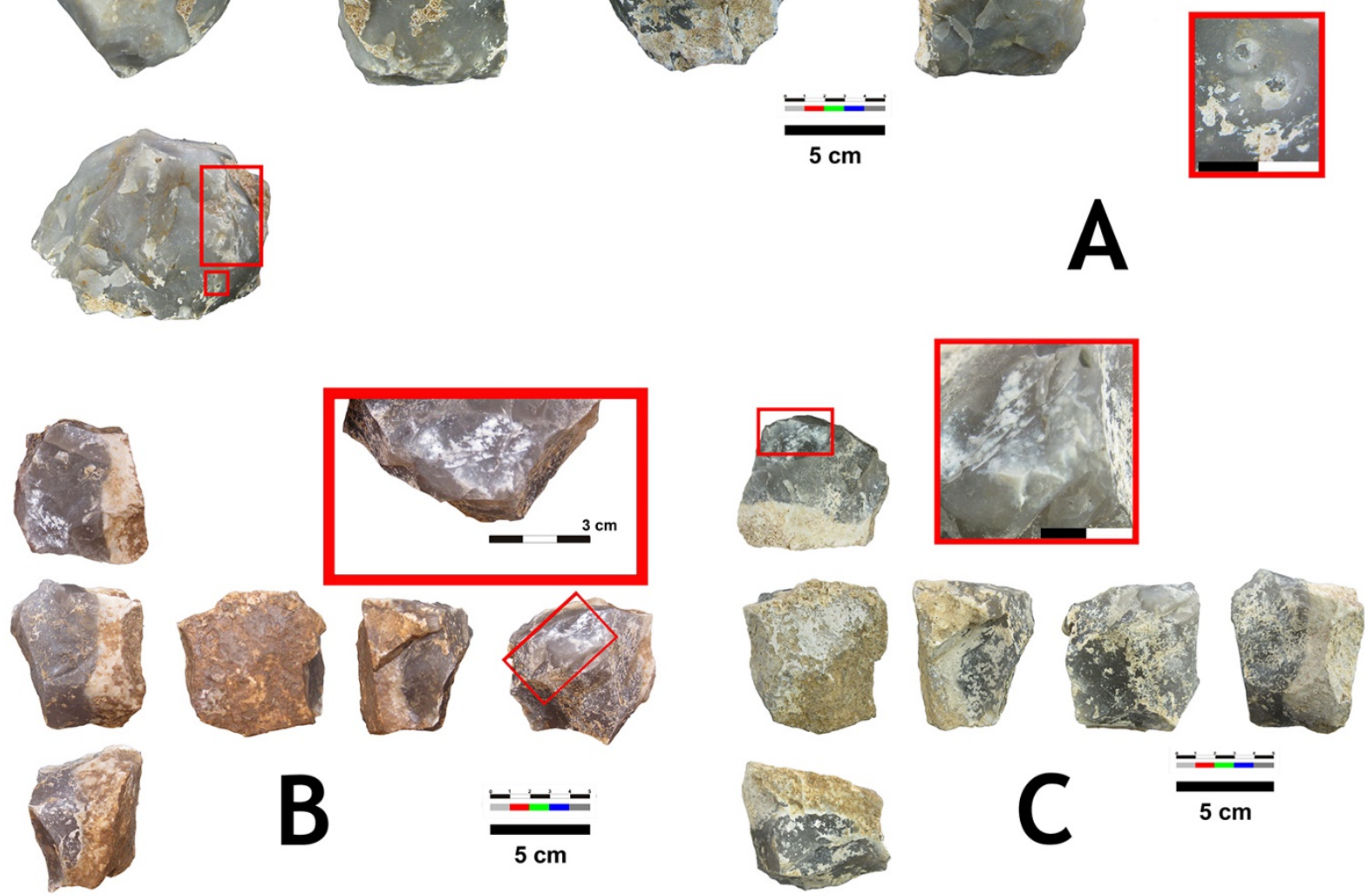

Figure 9. Selected flint hammerstones from the site CPD30. A) Large flint hammerstone. B \& C) Hammerstones with isolated and less intense percussion marks.

\subsection{Comparison of experimental results and archaeological samples}

Analysis and comparison of experimental and archaeological hammerstones has allowed us to record the following features:

a) In the experimental cases the weight of the hammerstones did not exceed 600 grams. However, most archaeological hammerstones exceed 600 grams. In most cases, this is due to the characteristics of the raw material to be knapped. Nodules used during the experimental 
protocols did not exceed in any case 3500 grams. In Parcela 32 and CPD30 there are two large hammerstones that may relate to the percussion of larger nodules (Tables 4 and 5).

b) In the case of experimental flint hammerstones, three of nine present two or more AZP, while six of 15 archaeological flint hammerstones present two or more AZP. This may be an indication of repeated use of the optimal zone (Tables 4 and 5).

Table 4. Metric analysis of archaeological flint hammerstones used in this study.1 Calabazas site; 2 CPD30 site; 3 P32 site.

Arch.

\begin{tabular}{|c|c|c|c|c|c|c|c|c|c|}
\hline Site ${ }^{\text {Ham. }}$ & $\begin{array}{l}\text { Weight } \\
\text { (g) }\end{array}$ & $\begin{array}{c}\mathrm{L} \\
(\mathrm{cm})\end{array}$ & $\begin{array}{c}W \\
(\mathrm{~cm})\end{array}$ & $\begin{array}{c}T \\
(\mathrm{~cm})\end{array}$ & $\begin{array}{c}V \\
\left(\mathrm{~cm}^{3}\right)\end{array}$ & $\begin{array}{l}\text { No. } \\
\text { ZAP }\end{array}$ & Zone 1 & Zone 2 & Zone 3 \\
\hline 1 & 211 & 5.6 & 5.2 & 5.8 & 66 & 1 & $2.2 \times 2.3$ & $1.5 \times 1$ & \\
\hline 1 & 201 & 6.1 & 5.8 & 5.3 & 60 & 1 & $3 \times 2$ & & \\
\hline 2 & 410 & 9.4 & 7.6 & 4.8 & 150 & 1 & $4.4 \times 1.5$ & & \\
\hline 2 & 216 & 7.8 & 6.2 & 5 & 80 & 2 & $2.5 \times 1.5$ & $1.5 \times 0.9$ & \\
\hline 2 & 101 & 4.6 & 4.5 & 3.9 & 40 & 1 & $2 \times 1.7$ & & \\
\hline 2 & 1148 & 11.7 & 9 & 7.8 & 450 & 1 & $3.3 \times 2.5$ & & \\
\hline 2 & 239 & 5.6 & 5.4 & 4.5 & 95 & 1 & $1.3 \times 1.9$ & & \\
\hline 2 & 724 & 10.7 & 9.1 & 6.6 & 270 & 1 & $2.9 \times 0.8$ & & \\
\hline 2 & 132 & 6.4 & 3.7 & 3.6 & 50 & 1 & $2.9 \times 1.1$ & & \\
\hline 3 & 1288 & 11.3 & 11 & 8.4 & 500 & 3 & $3.2 \times 1.8$ & $5.2 \times 3.5$ & $5.4 \times 1.2$ \\
\hline 3 & 597 & 8.5 & 7.3 & 6.1 & 240 & 2 & $1.8 \times 1.6$ & $1.9 \times 1.6$ & \\
\hline 3 & 700 & 7.8 & 7.6 & 6.6 & 260 & 1 & $4.3 \times 1.6$ & & \\
\hline 3 & 340 & 10.3 & 6.4 & 5.2 & 130 & 1 & $1.9 \times 1.6$ & & \\
\hline 3 & 253 & 9.4 & 6.4 & 4.2 & 100 & 2 & $4 \times 3.5$ & $0.6 \times 0.8$ & \\
\hline 3 & 746 & 13.3 & 10.6 & 4.4 & 300 & $1+2$ & $2.6 \times 0.8$ & $1.8 \times 0.4$ & $1.7 \times 0.4$ \\
\hline
\end{tabular}

Table 5. Metric analysis of experimental flint hammerstones used in this study.

\begin{tabular}{|c|c|c|c|c|c|c|c|c|c|c|}
\hline $\begin{array}{l}\text { Exp. } \\
\text { Ham. }\end{array}$ & $\begin{array}{c}\text { Weight } \\
\text { (g) }\end{array}$ & $\begin{array}{c}\mathrm{L} \\
(\mathrm{cm})\end{array}$ & $\begin{array}{c}W \\
(\mathrm{~cm})\end{array}$ & $\begin{array}{c}T \\
(\mathrm{~cm})\end{array}$ & $\begin{array}{c}V \\
\left(\mathrm{~cm}^{3}\right)\end{array}$ & $\begin{array}{l}\text { No. } \\
\text { ZAP }\end{array}$ & Zone 1 & Zone 2 & Zone 3 & Reduction system \\
\hline 13 & 192 & 6.9 & 5.5 & 4.5 & 75 & 1 & $2.6 \times 1.8$ & & & Levallois \\
\hline 16 & 416 & 9.2 & 8.8 & 5 & 65 & 3 & $1.8 \times 1.8$ & $1.3 \times 0.9$ & $1.9 \times 1.4$ & Discoid \\
\hline 17 & 296 & 9.2 & 6.5 & 4.8 & 110 & 1 & $2.3 \times 2$ & & & Discoid \\
\hline 18 & 498 & 8.9 & 8.8 & 5.5 & 200 & 1 & $2.1 \times 1.1$ & & & Levallois \\
\hline 19 & 438 & 7.5 & 6.9 & 6.8 & 170 & 2 & $2.6 \times 2.2$ & $1.3 \times 1.8$ & & Levallois \\
\hline 20 & 484 & 9.3 & 7.6 & 7.4 & 190 & 1 & $4.2 \times 3$ & & & Levallois \\
\hline 21 & 474 & 8 & 7.5 & 5.1 & 185 & 1 & $2.9 \times 1.8$ & & & Discoid \\
\hline 22 & 345 & 8.4 & 6.4 & 5.8 & 110 & 1 & $2.4 \times 0.9$ & & & Levallois \\
\hline 23 & 611 & 9.6 & 8.4 & 6.3 & 170 & 3 & $2.1 \times 2.5$ & $1.6 \times 1.9$ & $1 \times 1.8$ & Levallois \\
\hline
\end{tabular}

c) Size and weight are features that influence selection or discard when choosing a flint hammerstone. Thus, selection of flint hammerstones does not exclusively belong to an opportunistic behaviour. Despite the fact that flint is not an optimal raw material as a hammerstone, there is an intention in optimizing available materials through selection.

d) At the archaeological site of Parcela 32 we can observe the largest hammerstones. This seems to be related to the type of exploitation carried out in this archaeological site, where large flake blanks were sought after and obtained.

e) On the other hand, the archaeological site of Calabazas I presents hammerstones of small dimensions. The smaller dimensions of these hammerstones can be related to their use as retouchers (based on the high number of stone tools), but also with the presence of cores of 
small dimensions whose exploitation could not have been carried out effectively with larger hammerstones.

f) Morphological features observed in experimental hammerstones are equally defining when compared with archaeological hammerstones. We observe during discoidal reduction a preference for elements whose length exceeds the width and thickness. However, in the case of the Levallois technique, the flint hammerstones requires a larger impact area and selection tends to more spherical shapes.

g) Aspects such as breakage of the hammerstone are documented in Calabazas I (Figure $7 \mathrm{~B}$ ) as well as in experimental flint hammerstones (Figure 6). A major fracture tendency in flint hammerstones can be associated with expeditious use.

h) A box plot (Figure 10) to compare volume of experimental and archaeological hammerstones show that although volume variability is lower, it is in the range of the archaeological hammerstones.

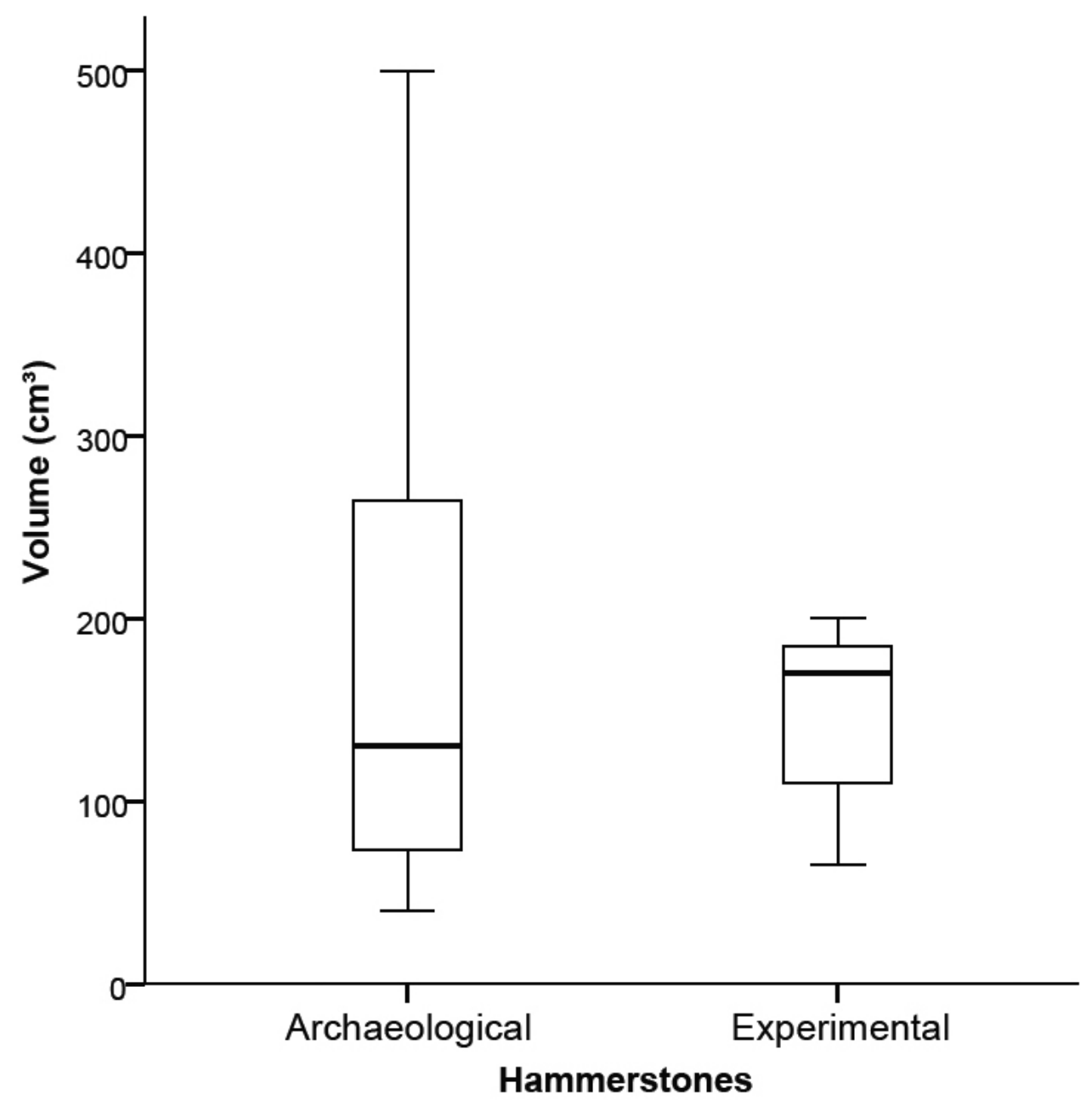

Figure 10. Box plot of experimental and archaeological hammerstones.

\section{Discussion and conclusions}

Despite difficulties in analysing the efficiency of flint hammerstones, significant data were obtained in this study. Even though flint hammerstones are not more effective than hammerstones in other raw materials, they represent a solution among different possibilities and resources provided by the environment. Flint hammerstones are functional, and as their use increases their efficiency also increases as a result of a smoother surface. However, as stigmas develop, the possibility of breakage increases. Another inconvenience is that some 
actions carried out during flint knapping, such as abrasion, are hard to do with a flint hammerstone resulting in a tendency for errors.

There seems to be some volumetric and morphological criteria followed when selecting flint cores that are recycled into hammerstones. Some of these criteria are size and weight according to knapping objectives, although flint core morphology is not optimal for percussion. Experimental analysis shows that this can be corrected by battering the surfaces that are going to be used as AZP. Although recycling is the main trend visible at our sites, some flint hammerstones are not product of recycling. In the analysed sample from Calabazas there is presence of a natural flint pebble used as a hammerstone. Experimental analysis and comparison with the archaeological remains have allowed for a deeper study of technical and technological behaviour of Palaeolithic groups in the central Iberian Peninsula. Some of these behaviours seem to be recurrent in this kind of environment. Adapting through selection, recycling or re-use, preparation and abandonment seems to represent a behaviour that underlies already acquired standards that are applied to specific environments.

Ongoing work (Baena et al. 2015b) indicates that use of flint hammerstones in the Madrid basin seemed to be a common feature during the Palaeolithic. Although it has been suggested elsewhere that flint hammerstones might present a higher technical efficiency without increasing the frequency of accidents (Claud et al. 2010), the experimental program developed here shows that knapping mistakes increase with the use of flint hammerstones.

\section{Acknowledgements}

This project is linked with the project: ¿Como, Quien y Donde? Variabilidad de Comportamientos en la Captacion y Transformacion de los Recursos Liticos Dentro de Grupos Neandertales (REF: HAR2013-48784-C3-3-P). Thanks also to Paleoaprende and Laboratorio de Arqueología Experimental members, especially Nuria Castañeda, Paloma de la Sota and Foivos Michos.

\section{References}

Baena, J.; Conde, C.; Carrión, E. \& Pastor, J. 2000, Paleolítico y Epipaleolítico. Boletín de la Asociación Española de Amigos de la Arqueología, (XXX Aniversario (1969-1999; La Arqueología Madrileña en el final del siglo XX: desde la Prehistoria hasta el año 2000), 39-40: 81-104. (in Spanish) (“Paleolítico y Epipaleolítico”)

Baena, J., Baréz, S., Pérez-González, A., Lázaro, Á., Nebot, A., Roca, M., Pérez, T., González, I., Cuartero, F., Rus, I., Polo, J., Márquez, R., Cabanes, D. \& Carrancho, A. 2008, El yacimiento paleolítico Cañaveral (Coslada-Madrid). La captación de recursos líticos durante el musteriense Peninsular. Arqueoweb, 9(2): 1-32. (in Spanish) ("The Palaeolithic site of Cañaveral (Coslada-Madrid). Lithic raw material procurement during the Peninsular Mousterian”)

URL: http://pendientedemigracion.ucm.es/info/arqueoweb/pdf/9-2/baena.pdf

Baena, J., Baréz, S., Pérez-González, A., Roca, M., Lázaro, A., Márquez, R., Rus, I., Manzano, C., Cuartero, F., Ortiz, I., Rodríguez, P., Pérez, T., González, I., Polo, J., Rubio, D., Alcaraz, M. \& Escobar, A. 2011, Searchers and miners: first signs of Flint exploitation in Madrid's region. Proceedings of the 2nd International Conference of the UISPP Commission on Flint Mining in Pre-and Protohistoric Times (Madrid, 14-17 October 2009) (Capote, M., Consuegra, S., Díaz-del-Río, P. \& Terradas, X., Eds.), BAR International Series Vol. 2260, Archaeopress, Oxford: p. 203-220. 
Baena, J., Ortiz Nieto-Márquez, I., Torres Navas, C. \& Bárez, S. 2015a, Recycling in abundance: Re-use and recycling processes in the Lower and Middle Paleolithic contexts of the central Iberian Peninsula. Quaternary International, 361: 142-154. doi:10.1016/j.quaint.2014.07.007

Baena, J., Bárez, S., Torres, C., Vega, J., Rus, I., Roca, M., Castañeda, N. \& Lamas, V. 2015b, Aprendiendo a excavar: el yacimiento paleolítico de Los Ahijones-Sector G como modelo de investigación y formación. Cuadernos de Prehistoria y Arqueología, 41: 195-208. (in Spanish) ("Learning to dig: the Palaeolithic site of Los AhijonesSector G as an example of investigation and education") doi:10.15366/cupauam2015.41.013

Bárez, S. \& Pérez-González, A. 2007, Patrones de aprovechamiento minero prehistórico del Sílex de Casa Montero (Vicálvaro, Madrid). XII Reunión Nacional de Cuaternario, (Lario, J. \& Silva, P; Eds.). Ávila: p: 91-92. (in English) ("Patterns of prehistoric mining exploitation of Casa Montero")

URL: http://tierra.rediris.es/aequa/doc/contribuciones_al_estudio_del_periodo_cuaterna rio.pdf

Bárez, S., Rus, I., Pérez-González, A. \& Vega De Miguel, J. 2011, Los yacimientos achelenses de Los Ahijones; metodología geoarqueológica y resultados de la intervención. In: Actas de las quintas jornadas de patrimonio arqueológico en la Comunidad de Madrid (Santonja Gómez, M., Ed.), Museo Arqueológico Regional, Madrid: p. 185-200. (in Spanish) ("The Acheulean sites of Los Ahijones; geoarcheological methods and results of the intervention”).

Bravo, M., Torres, C., Baena, J., 2013. Variabilidad en los modelos de captación y explotación política durante el achelense y musteriense en el yacimiento paleolítico "El Cañaveral”. In: VII Reunión de Cuaternario Ibérico (Baena, R., Fernández, J., Guerrero, I., Eds.), Aequa, Sevilla: p.73-77. (in Spanish) ("Varibility in raw material catchment and explotation models during the Acheulian and Mousterian at El Cañaveral Paleolithic site, Coslada, Madrid (Spain)”) URL: http://tierra.rediris.es/aequa/doc/El_Cuaternario_Iberico_2013.pdf

Bustillo, M.A. \& Pérez-Jiménez, J.L. 2005, Características diferenciales y génesis de los niveles silíceos explotados en el yacimiento arqueológico de Casa Montero (Vicálvaro, Madrid). Geogaceta, 38: 243-246. (in Spanish) ("Differential features and genesis of silica levels mined in the Casa Montero archaeological site. (Vicálvaro, Madrid)”). URL: http://rabida.uhu.es/dspace/bitstream/handle/10272/8693/Caracteristicasdiferenciales.pdf

Calvo, J.P., Zarza, A.M.A., del Cura, M.A.G., Ordóñez, S., Aranda, J.P.R., Montero, M.E.S., 1996. Sedimentary evolution of lake systems through the Miocene of Madrid Basin: paleoclimatic and paleohydrological constraints. In: Paleoclimatic and Paleohydrological Constraint. Tertiary Basins of Spain: The Stratigraphic Record of Crustal Kinematics (Friend, P.F., Dabrio, J.C., Eds.), Cambridge University Press, Cambridge: p. 272-277. doi:10.1017/CBO9780511524851.038

Claud, É., Mourre, V., Thiébaut, C. \& Brenet, M. 2010, Le recyclage au Paléolithique moyen. Des bifaces et des nucléus utilisés comme percuteurs. Archéopages, 29: 6-15. (in French) ("The recycling in the Middle Palaeolithic. Bifaces and cores used has hammerstones”) 
Cuartero, F., 2010. Estudio analítico de los percutores de TAFESA (Madrid). (Ejemplar dedicado a: Las huellas de nuestro pasado). Estudio del Yacimiento del pleistoceno madrileño de Tafesa (Antigua Transfesa). Zona Arqueológica, 14: 203-208. ("Analytical study of the hammerstones from TAFESA (Madrid)").

Cuartero, F. 2014, Percutores y retocadores: Interpretación de comportamientos técnicos en el Paleolítico medio peninsular desde el análisis del instrumental del tallador. Ph.D. thesis, Departamento de Prehistoria y Arqueología. Universidad Autónoma de Madrid, Madrid, 409 p. (in Spanish) ("Hammers and retouchers: Interpretation of technical behaviour in the Middle Palaeolithic in Iberian Peninsula from the analysis of knapping's instruments”)

Gibaja Bao, J.F. 2009, La reutilización de los instrumentos de sílex. Algunos ejemplos documentados en yacimientos neolíticos de la Península Ibérica. Salduie, 9: 23-35. ("The reutilization of flint tools: a few examples from Iberian Neolithic sites")

Giner, J.L., de Vicente, G., Pérez González, A., Sánchez Cabañero, J.G. \& Pinilla, L. 1996, Crisis tectónicas cuaternarias en la cuenca de Madrid. Geogaceta, 20(4): 842-845. (in Spanish) ("Madrid basin Quaternary tectonic crisis").

URL: http://www.sociedadgeologica.es/archivos/geogacetas/Geo20\%20(4)/Art25.pdf

López-Camacho, B., Bascones, M., De Bustamante, I. 1986. El agua subterránea en Madrid. Bol. Inform. y Estudios. Servicio Geológico, MOPU, 46: 128. ("The underground water of Madrid") (in Spanish)

Moncel, M.-H. 1999, Les Assemblages lithiques du site pléistocène moyen d'Orgnac 3 (Ardèche, Moyenne Vallée du Rhône, France): contribution à la connaissance du Paléolithique moyen ancien et du comportement technique différentiel des Hommes au Paléolithique inférieur et au Paléolithique moyen. Etudes et recherches archéologiques de l'Université de Liège Vol. 89, Liège, 446 p. (in French) (“The lithic assemblages of the Middle Pleistocene site of Orgnac 3 (Ardeche, Mid Rhone Valley, France): contribution to the knowledge of the ancient Middle Palaeolithic and the differential technical behavior of Men in the Lower Palaeolithic and Middle Palaeolithic periods”)

Rus, I. 1987. El Paleolítico. In: 130 Años Arqueología Madrileña, Real Academia de Bellas Artes San Fernando, Madrid: p. 20-43. (in Spanish) (“The Paleolithic”)

Thiébaut, C., Claud, É., Mourre, V., Chacón Navarro, M.-G., Asseline, G., Brenet, M. \& Paravel, B. 2010, Le recyclage et la réutilisation de nucléus et de bifaces au Paléolithique Moyen en Europe Occidentale: quelles fonctions et quelles implications culturelles? P@lethnologie, Varia, 41 p. (“The recycling and reuse of cores and bifaces during the Middle Palaeolithic in Western Europe: what functional and what cultural interpretations?”) (in French). URL: http://blogs.univ-tlse2.fr/palethnologie/wpcontent/files/2010/fr-FR/Palethnologie-2010-FR-Varia-Thiebaut-etalii.pdf

Torres, C. \& Baena, J. 2014, Querer hacer y poder hacer: la variabilidad en las industrias líticas y su relación con las habilidades técnicas y tecnológicas. Anejos a Cuadernos de Prehistoria y Arqueología Universidad Autónoma de Madrid (CuPAUAM), 1: 13-22. ("Want to do and be able to: variability in lithic industries and their relationship with the technical and technological skills”). doi:10.15366/anejos.galan2014.001 